Prezados Editores,

Agradecemos a oportunidade de resposta à correspondência assinada pelo Dr. Gerson Penna que nos foi oferecida. Também temos que cumprimentálos pela excelência do trabalho que os Senhores vêm desenvolvendo frente aos $\mathrm{ABD}$, sobretudo pela forma democrática com que os manuscritos enviados têm sido avaliados pelos referees. Esta mesma característica permitiu que os autores e os pareceristas julgassem suficientes as referências mencionadas no estudo "Prevalência de dermatoses na rede básica de Campinas, São Paulo, Brasil”.

Estranhamos que o correspondente julgue imperativo, termo por ele utilizado, o seu critério de redação, submissão e avaliação.

O trabalho de autoria institucional da SBD mencionado foi por ele coordenado enquanto VicePresidente da Sociedade. Foi enviado dia 14 de dezembro e aceito dia 18, sendo publicado imediatamente no fascículo de novembro/dezembro do volume daquele mesmo ano.

Lamentamos, de nossa parte, que ele não tenha enxergado no nosso estudo mais um esforço para a contribuição à formulação de políticas públicas, mas apenas a ausência da citação do seu manuscrito.

Respeitosamente,

Prof. Dr. Paulo Eduardo Neves Ferreira Velho

\title{
Nota dos Editores
}

Em relação à correspondência acima, de autoria do Dr. Paulo Eduardo Neves Ferreira Velho, os editores dos Anais Brasileiros de Dermatologia informam que os critérios de prioridade para publicação de artigos obedecem a múltiplos quesitos e que a determinação destes é de sua competência única e exclusiva.
$O$ artigo a que se refere o remetente é de autoria institucional, como ele próprio reconhece, e portanto não pertence a qualquer membro da diretoria. Foi publicado no volume $81, \mathrm{n}^{\circ} 6$, novembro/dezembro por ser o último fascículo editado na gestão $2005 / 2006$.

Os Editores 